\title{
Pengaruh Proses Pengolahan dan Penyangraian Biji Terhadap Aktivitas dan Kandungan Senyawa Antioksidan Sari Kedelai Hitam Mallika (Glycine max)
}

\author{
Wahidah Mahanani Rahayu', Erna Astuti² \\ ${ }^{1}$ Program Studi Teknologi Pangan FTI UAD, Kampus III, Jl. Prof. Dr. Supomo, SH, Janturan, Warungboto, \\ Yogyakarta 55164 \\ ${ }^{2}$ Program Studi Teknik Kimia FTI UAD, Kampus III, J1. Prof. Dr. Supomo, SH, Janturan, Warungboto, \\ Yogyakarta 55164 \\ *email: wahidah.rahayu@tp.uad.ac.id
}

\begin{abstract}
Black soybean roasting at certain temperature and period was reportedly able to increase its antioxidant activity. This research aimed to evaluate black soybean antioxidant properties after processed into soybean milk. After roasting at $200^{\circ} \mathrm{C}$ for 30 minutes, roasted and non-roasted black soybean were water-soaked for 12 hours. Soaked beans from both treatments were divided into two parts. First part was steamed for 30 minutes then ground with room temperature water. The second was not steamed but ground with $80^{\circ} \mathrm{C}$ water addition. After filtration, soybean milk was subjected to antioxidant activity, total phenolics, total flavonoids, and anthocyanin content analyses. Steamed-roasted soybeans milk had the highest antioxidant activity of 43.608\%, but it contained significantly lower phenolics, flavonoids, and anthocyanin than non-roasted beans. Total phenolic compounds, flavonoids, and anthocyanin content of roasted beans were 37.99-33.8\%, 15\%, 16.57 $-27.53 \%$ lower than those of non-roasted beans, compared in steamed and hot-water added milk. Generally, milk from non-steamed and hot water added beans had higher total phenolics and flavonoids than those from steamed beans, while anthocyanin content remained higher in steamed soybean milk. The results suggested that there was other compounds which responsible on roasted beans antioxidant activity, other than phenolic compounds, flavonoids, and anthocyanin. Comparison of soybean milk processing method indicated than steaming was able to preserve non-phenolics and non-flavonoid antioxidative compounds generated during roasting, whereas $80^{\circ} \mathrm{C}$ water addition without steaming might optimize phenolics and flavonoids compound extraction.
\end{abstract}

Keywords: antioxidant, black soybean milk, roasting

\section{Pendahuluan}

Beberapa tahun terakhir, banyak penelitian telah dilakukan untuk mengetahui potensi antioksidan dan manfaat kesehatan kedelai hitam. Kedelai hitam diketahui lebih unggul dibandingkan jenis kedelai lainnya dengan kandungan senyawa antioksidan dan rata-rata aktivitas penangkapan terhadap radikal bebas 2,45-2,85 kali lipat lebih tinggi dari kedelai kuning dan hijau [1]. Kedelai merupakan sumber antioksidan berupa antosianin pada bagian kulitnya, dan senyawa flavonoid pada bagian biji. Hal ini disebabkan kandungan phenolic acid, antosianin, dan isoflavon (daidzein, genistein) pada kedelai hitam yang lebih tinggi dibandingkan dengan kedelai kuning [2,3]. Kulit kedelai mengandung antosianin yang mempunyai aktivitas antioksidan besar, bahkan diketahui lebih tinggi dibandingkan tokoferol [4]. Kulit kedelai hitam juga diketahui mengandung polifenol sianidin 3-glukosida, katekin, epikatekin, prosianidin A, prosianidin B, prosianidin C, sinamtannin [5]. Penelitian mengenai persebaran kandungan total fenol, antosianin, dan isoflavon pada kulit, biji kupas (dehulled bean), dan biji utuh kedelai hitam melaporkan bahwa meski sebagian besar aktivitas antioksidan berasal dari bagian kulit yang tinggi antosianin, namun bagian biji kupas mengandung senyawa malonilglukosida dan nilai total isoflavon yang lebih tinggi daripada bagian kulit maupun kedelai utuh [6].

Karena kandungan berbagai senyawa aktif tersebut, kedelai hitam telah banyak dipelajari untuk upaya pencegahan dan terapi kesehatan sebagai agensia antioksidasi, antiinflamasi, dan antikanker. Antioksidan pada bahan ini mampu mengikat radikal bebas seperti $\mathrm{O}_{2}^{\bullet-}, \mathrm{OH}^{\bullet-}, \mathrm{ROO}^{\bullet-}$ (radikal peroxyl), nitric oxide, dan menghambat peroksidasi lipid yang diinduksi $\mathrm{Cu}^{2+}, \mathrm{Fe}^{2+}$ dan radiasi sinar ultraviolet [7]. Kedelai hitam Indonesia varietas Mallika dan Cikuray dengan kandungan senyawa fenolik dan antosianidin yang tinggi juga diketahui mampu menghambat oksidasi akibat LDL pada manusia [8]. Pada tikus diabetik, kedelai hitam juga dapat memperbaiki profil lipid [9] serta memperbaiki profil glukosa dan mencegah kerusakan pankreas [10]. 
Produk olahan fungsional berbahan kedelai hitam telah banyak dikembangkan agar dapat dimanfaatkan untuk masyarakat luas, antara lain minuman isotonik, minuman bubuk instan, juga yogurt dan kefir dari sari kedelai hitam $[11,12,13]$. Dalam pengolahannya, kedelai hitam mengalami perebusan, pengukusan, atau penambahan air bersuhu tinggi untuk mengekstrak protein maupun deaktivasi komponen antigizi, misalnya, enzim lipoksigenase, antitrypsin, dan hemaglutinin [14,15]. Selain perebusan dan pengukusan pada berbagai variasi waktu dan suhu, sari kedelai hitam juga dapat dibuat dengan menambahkan air bersuhu tinggi, antara $80-100{ }^{\circ} \mathrm{C}$ pada saat penggilingan [16]. Namun perlakuan suhu tinggi tersebut diketahui dapat menurunkan kandungan senyawa antioksidan sehingga menurunkan efek antiproliferatif terhadap sel kanker [17], yang menunjukkan penurunan manfaat kesehatan yang dapat diperoleh. Di sisi lain, penyangraian kedelai hitam menggunakan penyangrai kopi pada suhu dan waktu tertentu dilaporkan dapat menghambat penurunan aktivitas antioksidan melalui pelepasan senyawa antoksidan terlarut yang sebelumnya masih terikat pada jaringan [18] maupun produksi senyawa hasil reaksi Maillard akibat penyangraian yang memiliki aktivitas penghambatan radikal bebas [2].

Meski terdapat berbagai penelitian mengenai berbagai manfaat kesehatan serta pengaruh pemanasan terhadap sifat-sifat antioksidatif berbagai varietas kedelai hitam, namun belum terdapat laporan mengenai pengaruh penyangraian terhadap aktivitas dan kandungan senyawa antioksidan berupa senyawa fenolik, flavonoid, dan antosianin dalam produk olahan sari kedelai hitam di Indonesia, khususnya varietas Mallika. Oleh karena itu, penelitian ini dilakukan untuk mempelajari perubahan aktivitas dan kandungan senyawa antioksidan sari kedelai hitam varietas Mallika. Diharapkan penelitian ini dapat memberi informasi tentang proses pengolahan kedelai hitam yang dapat mengoptimalkan manfaat kesehatan dalam produk olahannya.

\section{Metodologi}

\section{Bahan Percobaan}

Bahan yang digunakan dalam penelitian ini adalah kedelai hitam varietas Mallika yang diperoleh dari Pacitan, Jawa Timur. Bahan kimia yang digunakan untuk ekstraksi adalah etanol $96 \%$ pro-analisis. Sedangkan bahan kimia untuk analisis meliputi aquades, metanol teknis, metanol HPLC grade DPPH, heksan, reagen Folin-Ciocalteu, $\mathrm{Na}_{2} \mathrm{CO}_{3} 7,5 \%, \mathrm{CH}_{3} \mathrm{COOK}, \mathrm{Al}_{2} \mathrm{CO}_{3}$, asam gallat, katekin, $\mathrm{HCl} \mathrm{0,02} \mathrm{N}, \mathrm{NaOH} 1 \mathrm{M}$.

\section{Alat Percobaan}

\section{Penyangraian dan Pembuatan Sari Kedelai Hitam}

Proses penyangraian dilakukan berdasarkan metode yang dilakukan oleh Kim [2] dan Thidarat [18] dan dengan modifikasi. Kedelai hitam ditempatkan ke dalam alat sangrai kopi (coffee roaster) pada suhu $200{ }^{\circ} \mathrm{C}$ selama 30 menit. Biji kedelai hitam sangrai dan non-sangrai sebagai pembanding kemudian direndam selama 12 jam dengan perbandingan bahan : air sebesar $1: 5[12,15]$. Setelah penirisan, kedelai hitam sangrai dan nonsangrai masing-masing dibagi menjadi dua bagian. Bagian satu diberi perlakuan pengukusan selama 30 menit dilanjutkan penggilingan bersama air suhu kamar dan bagian dua dengan perlakuan tanpa pengukusan dilanjutkan penggilingan bersama air bersuhu $80^{\circ} \mathrm{C}$, seluruhnya dengan perbandingan bahan : air sebesar 1:10. Dengan demikian, diperoleh 4 jenis sampel yaitu sangrai + kukus + air suhu kamar (RSR), sangrai + tidak dikukus + air bersuhu $80^{\circ} \mathrm{C}$ (RHW), non-sangrai + kukus + air suhu kamar (NRSR), dan non-sangrai + tidak dikukus + air bersuhu $80{ }^{\circ} \mathrm{C}$ (NRHW). Setelah penyaringan dan dididihkan selama 60 detik, sari kedelai disimpan dalam botol gelap berperekat dan lemari pendingin sebelum pengujian.

\section{Analisis}

\section{Aktivitas antioksidan}

Aktivitas antioksidan sampel diukur dengan metode penghambatan radikal DPPH [19]. Sebanyak 0,1 ml sampel dalam metanol PA konsentrasi 100 ppm ditambahi dengan 0,5 ml larutan DPPH 0,5 mM (dalam metanol). Kemudian $4 \mathrm{ml}$ metanol ditambahkan dan diinkubasi selama 60 menit dalam ruangan gelap. Kontrol mengandung 0,5 ml DPPH dan $4 \mathrm{ml}$ metanol. Penurunan absorbansi DPPH pada panjang gelombang $516 \mathrm{~nm}$ spektrofotometer (Shimadzu 1601) menunjukkan peningkatan aktivitas pengikatan radikal DPPH. Persen penangkapan radikal bebas DPPH dihitung menggunakan rumus berikut:

$\%$ penangkapan radikal DPPH = absorbansi kontrol - absorbansi sampel $\times 100 \%$

$$
\text { absorbansi kontrol }
$$

\section{Analisis total antosianin}

Uji total antosianin dengan metode $\mathrm{pH}$ differential methods dilakukan berdasarkan perubahan warna antosianin sebagai fungsi dari $\mathrm{pH}$ [20]. Tahap pertama adalah penyiapan larutan buffer 1 dengan mencampurkan 1,49 $\mathrm{g} \mathrm{KCl}$ ke dalam $100 \mathrm{ml}$ aquades dan ditambahi $\mathrm{HCl}$ pekat tetes demi tetes hingga $\mathrm{pH} 1$ 
dan buffer 2 dengan mencampurkan 1,64 g Na asetat ke dalam $100 \mathrm{ml}$ akuades dan ditambahi $\mathrm{HCl}$ pekat tetes demi tetes hingga $\mathrm{pH} 4,5$. Analisis dilakukan dengan mencampur masing-masing $0,02 \mathrm{ml}$ sampel dengan 11,98 $\mathrm{ml}$ buffer 1 dan buffer 2 (FP 600), kemudian didiamkan selama 15 menit. Absorbansi masing-masing sampel dan blanko berisi akuades diukur dengan spektrofotometer pada panjang gelombang $510 \mathrm{~nm}$ and $700 \mathrm{~nm}$ maksimal 1 jam setelah pencampuran. Antosianin dihitung sebagai monomer sianidin-3-glikosida dengan rumus berikut:

$$
\text { Antosianin }(\mathrm{mg} / \mathrm{L})=\frac{\left[\left(\mathrm{A}_{510}-\mathrm{A}_{700}\right) \mathrm{pH} 1-\left(\mathrm{A}_{510}-\mathrm{A}_{700}\right) \mathrm{pH} 4,5\right]}{\varepsilon \times \mathrm{L}} \times \mathrm{BM} \times \mathrm{FP}
$$

Analisis total senyawa fenolik

Total senyawa fenolik diukur dengan metode Folin-Ciocalteu dengan standar asam galat (Gallic Acid Equivalent/GAE) sebagaimana prosedur yang dilakukan oleh [21] dengan perubahan. Sebanyak 0,25 ml susu kedelai hitam ditambahi $0,75 \mathrm{ml}$ akuades sebagai stok sampel. Dari larutan ini, diambil sebanyak $0,2 \mathrm{ml}(3 \mathrm{x}$ ulangan) dan ditambahi dengan $1 \mathrm{ml}$ reagen Folin-Ciocalteu, digojog dengan vortex, dan diinkubasi selama 8 menit. Kemudian ditambahkan $0,8 \mathrm{ml}$ larutan $\mathrm{Na}$ karbonat $\left(\mathrm{Na}_{2} \mathrm{CO}_{3}\right) 2 \%$ dan diinkubasi pada suhu kamar selama 30 menit. Blanko yang digunakan adalah metanol, sedangkan kurva standar dibuat dengan asam galat pada konsentrasi $10-100 \mu \mathrm{g} / \mathrm{ml}$. Absorbansi diukur pada panjang gelombang $760 \mathrm{~nm}$ dengan spektrofotometer (Shimadzu UV-1601). Konsentrasi total senyawa fenolik dihitung dengan menggunakan kurva standar asam galat.

\section{Analisis total flavonoid}

Metode kolorimetri standar katekin berdasar prosedur yang dilakukan [22] dengan sedikit perubahan digunakan untuk mengukur kadar flavonoid. Sebanyak $1 \mathrm{~mL}$ aliquot larutan standar katekin berbagai konsentrasi (0-100 mg/L) dan sampel ditambahi dengan dengan $4 \mathrm{~mL}$ akuades. Sebanyak 0,3 mL larutan $\mathrm{NaNO}_{2} 5 \%$ ditambahkan, diinkubasi selama 5 menit, kemudian ditambahi 0,3 mL larutan $\mathrm{AlCl}_{3}$ 10\%. Setelah 6 menit, ditambahkan $2 \mathrm{~mL} \mathrm{NaOH} 1 \mathrm{M}$ dan akuades hingga volume total $10 \mathrm{~mL}$. Campuran digojog dengan vortex. Absorbansi sampel dan blanko diukur pada panjang gelombang $510 \mathrm{~nm}$. Pengujian dilakukan secara triplo. Konsentrasi flavonoid dihitung dengan menggunakan kurva standar kuersetin.

\section{Rancangan percobaan dan analisis statistika}

Percobaan ini menggunakan Rancangan Acak Lengkap dengan asumsi kondisi sampel homogen dengan varietas dan lokasi penanaman yang sama, serta kondisi ekstraksi sama. Setiap pengambilan data dilakukan tiga kali ulangan. Data dinyatakan sebagai rata-rata \pm SD. Penelitian ini menggunakan satu variabel independen, yaitu lama waktu penyangraian. Semua data yang diperoleh dianalisis dengan ANOVA pada tingkat kepercayaan 95\% dengan menggunakan program SPSS 18. Jika terdapat perbedaan nyata, analisis dilanjutkan dengan uji DMRT untuk mengetahui signifikansi perbedaan.

\section{Hasil dan Pembahasan}

Hasil

Aktivitas Antioksidan

Pengukuran aktivitas antioksidan diperlukan untuk membuat perkiraan awal proses pengolahan yang dapat menghasilkan sari kedelai dengan aktivitas tertinggi, diukur dengan metode pengikatan radikal DPPH. Aktivitas antioksidan tertinggi diperoleh sari kedelai yang diolah melalui penyangraian dan pengukusan dengan penambahan air masak bersuhu kamar pada saat penggilingan sebesar 43,608\%, diikuti oleh sari kedelai non sangrai dengan perlakuan serupa sebesar 26,499\% (Gambar 1).

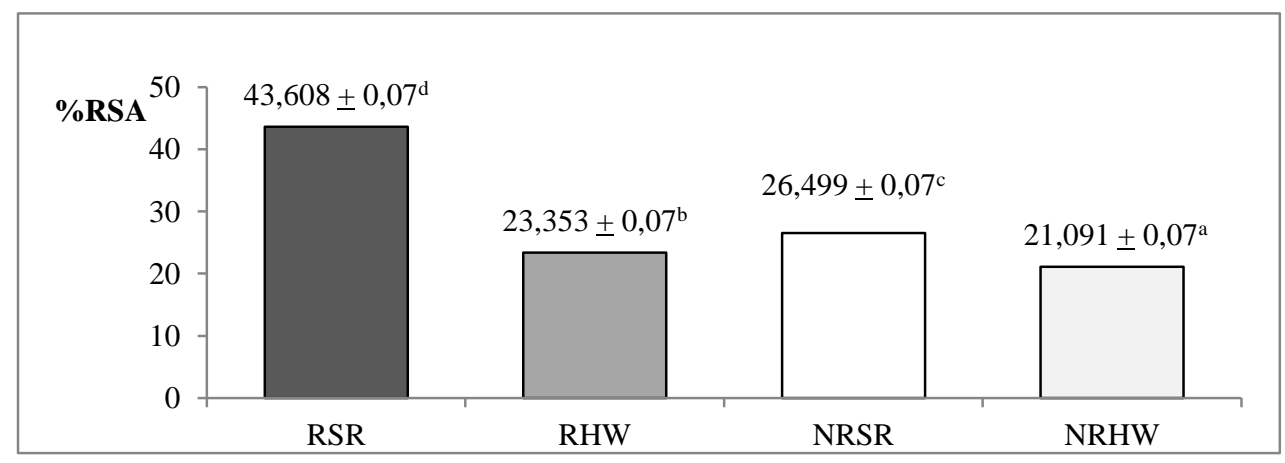

Gambar 1. Aktivitas Antioksidan Sari Kedelai Hitam Mallika pada Berbagai Variasi Perlakuan 
$\% \mathrm{RSA}=\%$ radical scavenging activity

Hasil ditampilkan sebagai rerata \pm SD dari dua kali ulangan

Beda signifikan dihitung pada $\alpha<0,05$,

Sari kedelai yang diolah tanpa pengukusan dengan penambahan air panas saat penggilingan memiliki aktivitas yang hampir serupa dan lebih rendah daripada sari kedelai yang dikukus, baik pada kedelai yang disangrai maupun non-sangrai. Hasil tersebut menunjukkan bahwa senyawa-senyawa yang memiliki sifat pengikatan radikal bebas dapat dihasilkan pada saat penyangraian, serta lebih dapat diekstrak setelah mengalami pengukusan.

\section{Total Senyawa Fenolik}

Senyawa fenolik bertanggungjawab dalam aktvitas pengikatan radikal karena kemampuannya sebagai donor hidrogen yang menstabilkan radikal bebas [23]. Analisis ini dilakukan untuk menguji tingkat produksi senyawa fenol yang dihasilkan dari berbagai variasi proses pengolahan serta apakah senyawa tersebut berperan dalam aktivitas antioksidan sari kedelai hitam (Gambar 2).

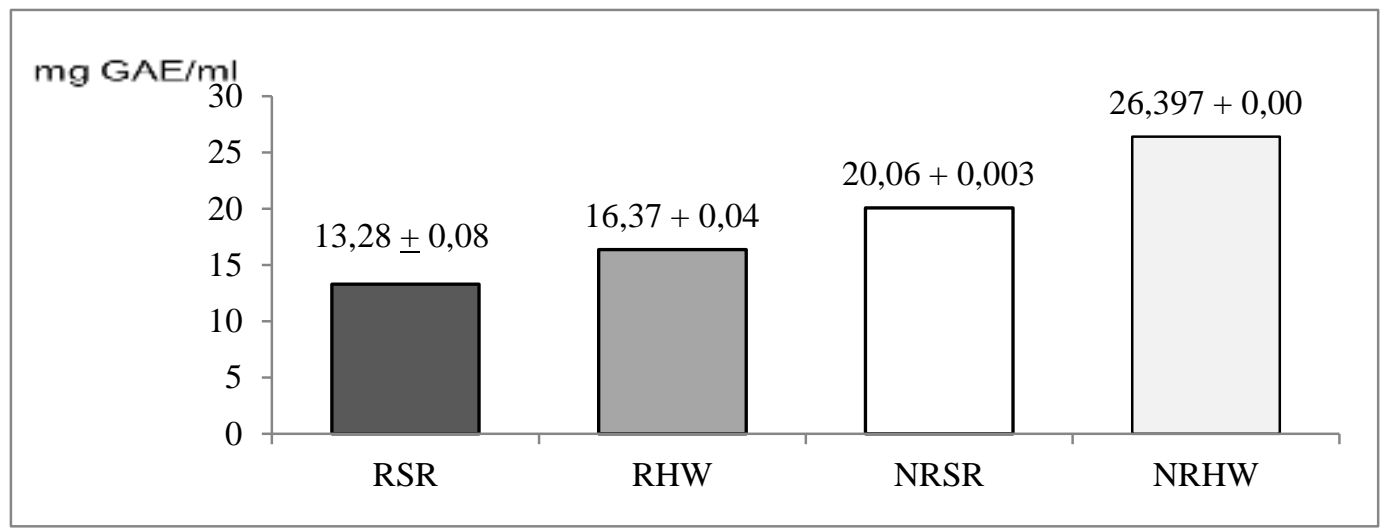

Gambar 2. Total Senyawa Fenolik Sari Kedelai Hitam Mallika pada Berbagai Variasi Perlakuan

mg GAE/ml : mg Gallic Acid Equivalent / ml

Hasil ditampilkan sebagai rerata \pm SD dari dua kali ulangan

Beda signifikan dihitung pada $\alpha<0,05$,

Berbeda dengan pola perubahan aktivitas antioksidan, total kandungan senyawa fenolik sari kedelai hitam Mallika lebih tinggi pada kedelai non-sangrai. Total senyawa fenolik sari kedelai non-sangrai lebih tinggi dari kedelai sangrai, dengan kandungan tertinggi sebesar 26,397\% diperoleh sampel yang tidak dikukus, dan digiling dengan penambahan air panas (NRHW), diikuti oleh sari kedelai non-sangrai yang dikukus dan digiling bersama air suhu kamar (NRSR) sebesar 20,06\%, kedelai sangrai tidak dikukus yang digiling dengan air panas (RHW) sebesar 16,37\%, dan kandungan senyawa fenolik terendah sebesar 13,28 diperoleh sari kedelai sangrai yang dikukus dan digiling dengan air suhu kamar. Untuk masing-masing sampel sangrai dan non-sangrai, total senyawa fenolik lebih tinggi pada sari kedelai yang tidak dikukus. Hal ini menunjukkan bahwa pengukusan menjadi penentu kandungan senyawa fenolik produk akhir.

Kim [2] dan Thidarat [18] melaporkan bahwa kandungan senyawa fenolik pada ekstrak etanolik kedelai hitam dan kedelai kuning meningkat dengan adanya penyangraian. Sedangkan [24] yang menguji perubahan fisikokimia kedelai kuning Kamerun akibat penyangraian pada suhu $110^{\circ} \mathrm{C}$ dan perendaman hingga 72 jam melaporkan bahwa kandungan senyawa fenolik mengalami penurunan akibat perendaman, dan semakin menurun seiring dengan waktu. Pada semua sampel, tingkat retensi senyawa fenolik yang diukur menggunakan ekstrak etanoliknya menunjukkan hasil yang lebih tinggi pada sampel yang disangrai. Sehingga jika dikaitkan dengan hasil penelitian ini, diduga kandungan senyawa fenolik yang dihasilkan selama penyangraian hilang selama pengukusan. Selain itu, dapat diduga bahwa senyawa fenolik larut air yang masih ada dalam biji kedelai sangrai maupun non-sangrai lebih dapat diekstrak menggunakan air panas $80^{\circ} \mathrm{C}$ selama penggilingan.

Total Flavonoid

Selain senyawa fenolik, kedelai hitam juga mengandung senyawa flavonoid yang memiliki aktivitas antioksidan. Hasil analisis flavonoid yang dilakukan untuk mengukur kandungan flavonoid yang dipengaruhi penyangraian, pengukusan, dan penambahan air pada variasi suhu $80^{\circ} \mathrm{C}$ dan suhu kamar (Gambar 3). 


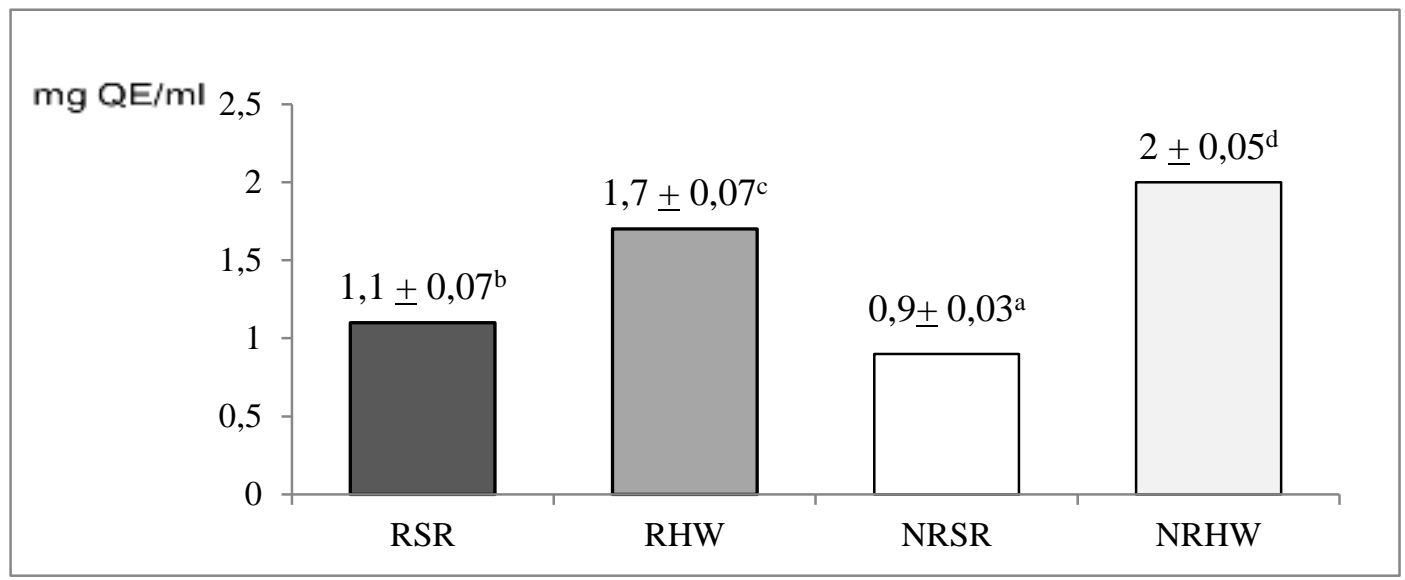

Gambar 3. Total Flavonoid Sari Kedelai Hitam Mallika pada Berbagai Variasi Perlakuan

$\mathrm{mg} \mathrm{QE} / \mathrm{ml}$ : mg Quercetin Equivalent / ml

Hasil ditampilkan sebagai rerata \pm SD dari dua kali ulangan

Beda signifikan dihitung pada $\alpha<0,05$,

Dari grafik di atas, baik pada kedelai sangrai maupun non sangrai, level flavonoid lebih tinggi pada kedelai tidak dikukus dan ditambahi air panas saat penggilingan dengan kadar flavonoid tertinggi diperoleh sari kedelai hitam non sangrai sebesar $2 \mathrm{mg} / \mathrm{ml}$ diikuti sari kedelai sangrai yang tidak dikukus sebesar 1,7 mg/ml. Di antara sampel yang dikukus, sari kedelai yang disangrai memiliki kandungan flavonoid yang lebih tinggi daripada sari kedelai non-sangrai. Dari data tersebut dapat diduga bahwa penyangraian membantu rilis flavonoid dari jaringan. Namun sebagian kandungan flavonoid hilang pada saat pengukusan.

\section{Antosianin}

Antosianin kedelai hitam terkandung dalam kulit biji. Bagian ini sekaligus yang paling banyak terpapar panas pada saat penyangraian (Gambar 4) Kadar antosianin berada pada kisaran 10,1 - 13,94 ppm atau setara dengan 0,0101 - 0,0139 mg/ml, dengan antosianin terendah pada sari kedelai sangrai kukus hasil penggilingan dengan air suhu kamar dan tertinggi pada sari kedelai non-sangrai yang dikukus.

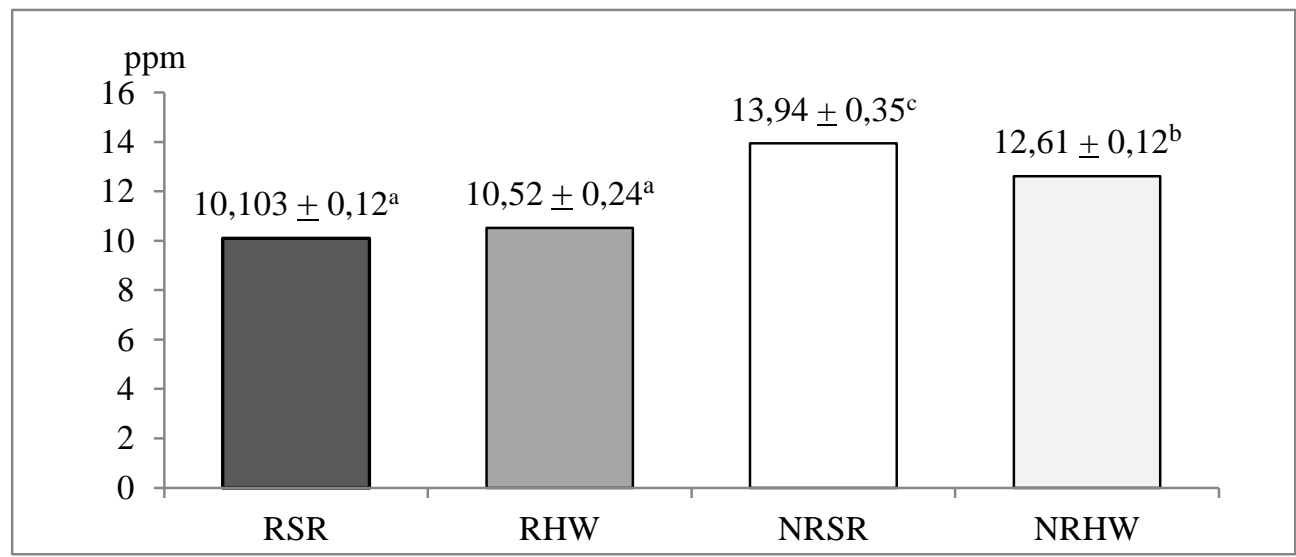

Gambar 4. Kadar Antosianin Sari Kedelai Hitam Mallika pada Berbagai Variasi Perlakuan

Hasil ditampilkan sebagai rerata \pm SD dari dua kali ulangan Beda signifikan dihitung pada $\alpha<0,05$,

Sari kedelai hasil sangrai memiliki kandungan antosianin yang secara signifikan lebih rendah daripada sampel non-sangrai. Tidak ada perbedaan antarsampel yang disangrai sehingga proses yang menentukan kandungan antioksidan adalah penyangraian. Pemberian air panas pada kedelai non-sangrai dapat mengurangi kadar antosianin dibandingkan perlakuan pengukusan.

\section{Pembahasan}

Hasil penelitian ini menunjukkan bahwa penyangraian mampu meningkatkan aktivitas antioksidan sari kedelai hitam. Hal ini sesuai yang telah dilaporkan oleh berbagai penelitian sebelumnya $[2,18,24]$. Tetapi 
seluruh penelitian tersebut belum mengukur kandungan senyawa antioksidan pada kedelai sangrai yang kemudian mengalami perlakuan pengolahan lanjutan. Sejauh yang peneliti ketahui, penelitian ini adalah penelitian pertama yang membahas tentang perubahan kandungan senyawa antioksidan kedelai sangrai jika mengalami perlakuan lanjutan atau pemanasan, dengan air sebagai pelarut. Hasil dari penelitian ini dapat digunakan sebagai informasi dalam pengolahan sari kedelai hitam sangrai.

Secara umum dapat dilihat bahwa perlakuan lanjutan, yaitu pengukusan dan penambahan air panas pada suhu $80^{\circ} \mathrm{C}$ dapat mengurangi kandungan total fenol, flavonoid, dan antosianin. Hasil ini mengkonfirmasi hasil penelitian Xu dan Chang [17] melaporkan bahwa pengukusan menurunkan kandungan senyawa fenolik kedelai hitam secara signifikan dibandingkan kedelai yang tidak dikukus dengan retensi senyawa fenolik lebih baik pada pressured steamed atau kukusan bertekanan. Diketahui bahwa meski penyangraian dapat meningkatkan rilis kandungan senyawa fenolik dari jaringan [18], peningkatan tersebut ternyata tidak mampu mengimbangi tingkat kehilangan akibat pemanasan selama pengolahan lanjutan. Tetapi di sisi lain, aktivitas antioksidan sari kedelai hitam sangrai yang dikukus justru paling tinggi di antara semua sampel. Hasil kontradiktif ini memberi dugaan bahwa terdapat senyawa lain yang bertanggung jawab dalam aktivitas antioksidan, selain dari senyawa fenolik, flavonoid, dan antosianin. Senyawa tersebut diduga merupakan hasil reaksi Maillard (Maillard reaction products) yang terbentuk akibat pemanasan, tetapi belum diukur dalam penelitian ini.

Tahapan yang juga menentukan hasil analisis adalah perendaman bahan selama 12 jam. Air sisa rendaman berwarna sangat keruh dan kehitaman (gambar ditampilkan dalam lampiran) menjadi indikasi bahwa terdapat material larut air yang hilang karena larut dalam air rendaman. Aktivitas antioksidan sari kedelai hitam Mallika lebih tinggi pada kedelai yang disangrai, baik kedelai yang dikukus maupun yang ditambahi air panas, demikian pula kedelai yang dikukus memiliki aktivitas antioksidan yang lebih tinggi daripada yang ditambahi air panas. Hal ini mengarahkan dugaan bahwa pengukusan dapat lebih mempertahankan senyawa antioksidatif non-fenolik dan non-flavonoid yang dihasilkan selama proses penyangraian. Selain itu, penggunaan air panas dapat meningkatkan ekstraksi senyawa tersebut pada saat penggilingan.

Selain beberapa dugaan di atas, terdapat kemungkinan bahwa senyawa aktif yang dihasilkan dalam penyangraian masih tertinggal dalam padatan ampas kedelai setelah penyaringan sari kedelai. Sehingga selain proses pemanasan, perlu penyelidikan lebih lanjut mengenai optimalisasi proses pengolahan sari kedelai untuk menghasilkan produk dengan kualitas yang lebih baik.

\section{Kesimpulan}

Aktivitas antioksidan sari kedelai hitam sangrai lebih tinggi daripada non-sangrai, terutama kedelai kukus dibandingkan yang ditambahi air suhu $80^{\circ} \mathrm{C}$. Kadar senyawa fenolik dan flavonoid kedelai sangrai menurun signifikan akibat pengukusan dan penambahan air suhu $80^{\circ} \mathrm{C}$. Retensi senyawa fenolik lebih tinggi dengan penambahan air suhu $80^{\circ} \mathrm{C}$. Direkomendasikan untuk mengolah sari kedelai hitam dengan pengukusan dan penambahan air pada suhu kamar karena menghasilkan sari kedelai hitam Mallika sangrai dengan aktivitas antioksidan yang lebih baik.

\section{Ucapan Terimakasih}

Peneliti mengucapkan terimakasih atas bantuan pendanaan penelitian melalui skim Penelitian Dosen Pemula dari Kopertis Wilayah V DIY, Kementerian Riset, Teknologi, dan Pendidikan Tinggi.

\section{Daftar Notasi}

$\mathrm{A}_{510}=$ absorbansi pada panjang gelombang $510 \mathrm{~nm}$, diukur pada $\mathrm{pH} 1 \mathrm{dan} \mathrm{pH} 7,5$

$\mathrm{A}_{700}=$ absorbansi pada panjang gelombang $700 \mathrm{~nm}$, diukur pada $\mathrm{pH} 1 \mathrm{dan} \mathrm{pH} 7,5$

$\mathrm{BM}=$ berat molekul sianidin-3-glikosida $(449,2)$

$\mathrm{FP}=$ faktor pengenceran $(600)$

$\varepsilon=$ molar absorptivitas sianidin 3-glikosida $(26.900 \mathrm{~L} / \mathrm{mol} . \mathrm{cm})$

$\mathrm{L}=$ cell path length $(1 \mathrm{~cm})$

$\mathrm{RSR}=$ kedelai sangrai, dikukus, air suhu kamar,

RHW = kedelai sangrai, tidak dikukus, air suhu $80^{\circ} \mathrm{C}$,

NRSR = kedelai non sangrai, dikukus, air suhu kamar,

NRHW = kedelai non-sangrai, tidak dikukus, air suhu $80^{\circ} \mathrm{C}$ )

\section{Daftar Pustaka}

[1] Kumar V., Rani, A., Dixit,A.K., Pratap, D., dan Bhatnagar, D. 2010. A comparative assessment of total phenolic content, ferric reducing-anti-oxidative power, free radical-scavenging activity, vitamin $\mathrm{C}$ and isoflavones content in soybean with varying seed coat colour. Food Research International 43:323-328. 
[2] Kim, H.G., Kim,G.W., Oh, H.E., Yoo, S.Y., Kim Y.O., dan Oh, M.S. 2011. Influence of roasting on the antioxidant activity of small black soybean (Glycine max L. Merrill). Food Science and Technology 44: 992-998.

[3] Xu, B.J., Yuan, S.H., dan Chang, S.K.C., 2008. Comparative Studies on the Antioxidant Activities of Nine Common Food Legumes Against Copper Induced Human Low-Density Lipoprotein Oxidation in vitro. Journal of Food Science 72(7): 211-218.

[4] Purwanti,S. 2004. Kajian suhu ruang simpan terhadap kualitas benih kedelai hitam dan kedelai kuning. Jurnal Ilmu Pertanian 11(1): 22-31.

[5] Zhang, Z.F., Lu, J., Zheng, Y.L., Wu, D.M., Hu, B., dan Shan, Q. 2013. Purple sweet potato color attenuates hepatic insulin resistance via blocking oxidative stress and endoplasmic reticulum stress in high-fat-diet-treated mice. The Journal of Nutritional Biochemistry 24: 1008-1018.

[6] Xu, B., dan Chang, S.K.C. 2008. Antioxidant capacity of seed coat, dehulled beanand whole black soybeans in relation to their distributions of total phenolics, phenolic acids, anthocyanins and isoflavones. Journal of Agricultural and Food Chemistry 56: 8365-8373.

[7] Kowalczyk, E., Krzesinski, P., Kura, M., Szmigiel, B., dan Blaszczyk, J. 2003. Anthocyanins in medicine. Poland Journal of Pharmacology 55: 699-702.

[8] Astadi, Ignasius Radix; Mary Astuti, Umar Santoso, Prihati Sih Nugraheni. 2008. In vitro antioxidant activity of anthocyanins of black soybean seed coat in human low density lipoprotein (LDL). Food Chemistry 112: 659-663.

[9] Kusumawardhani, A. 2014. Pengaruh campuran ekstrak antosianin beras hitam (Oryza sativa l.) Dan ekstrak protein kedelai hitam (Glycine max (l)merr.) terhadap profil lipid dan status antioksidanplasma tikus dyslipidemia. Tesis S-2. Prodi Ilmu dan Teknologi Pangan, Fakultas Teknologi Pertanian, UGM.

[10] Rahayu, W.M. Efektivitas ekstrak antosianin beras merah (Oryza sativa 1.) dan kedelai hitam (Glycine $\max (1)$ merr.) dalam penanggulangan hiperglikemia tikus induksi STZ - NA. Tesis S-2. Prodi Ilmu dan Teknologi Pangan, Fakultas Teknologi Pertanian, UGM.

[11] Agustia, F. C. 2009. Potensi antioksidatif formula bubuk kedelai hitam (Glycine max) sebagai minuman kesehatan pada penyandang diabetes mellitus tipe 2. Tesis S-2. Prodi Ilmu dan Teknologi Pangan, Fakultas Teknologi Pertanian, UGM.

[12] Maharani, S. 2014. Pengaruh suhu dan jumlah inokulum terhadap perubahan kimia, fisik dan mikrobiologis yogurt susu kedelai hitam dengan inokulum Caspian Sea yogurt. Tesis S-2. Prodi Ilmu dan Teknologi Pangan, Fakultas Teknologi Pertanian, UGM.

[13] Nurdyansyah, F. 2016. Effect of goat-and-soymilk mixture kefir on microorganism and physico-chemical properties of STZ-NA induced diabetic rats digesta. Tesis S-2. Prodi Ilmu dan Teknologi Pangan, Fakultas Teknologi Pertanian, UGM.

[14] Koswara, S. 2009. Teknologi Pengolahan Kedelai (Teori dan Praktek). Universitas Muhammadiyah Semarang, Semarang.

[15] Santoso. 2009. Susu dan Yoghurt Kedelai. Laboratorium Kimia Pangan Faperta. Universitas Widya Gama, Malang.

[16] Kusumaningrum, R. D. 2013.Fermentasi Susu Kedelai Hitam Menggunakan Kultur Caspian Sea Yogurt. Tesis S-2. Fakultas Teknologi Pertanian. Universitas Gadjah Mada.

[17] Xu B.J. dan Chang S.K.C., 2011. Reduction of antiproliferative capacities, cell-based antioxidant capacities and phytochemical contents of common beans and soybeans upon thermal processing. Food Chemistry 129:974-981.

[18] Thidarat, S., Udomsak, M., Jindawan, W., Namphung, D., Suneerat, Y., Sawan, T., dan Pisamai, T. 2016. Effect of roasting on phytochemical properties of Thai soybeans. International Food Research Journal 23(2): 606-612.

[19] Brand-Williams, W., Cuvelier, M.E. and Berset, C.L.W.T., 1995. Use of a free radical method to evaluate antioxidant activity. LWT-Food science and Technology, 28(1), pp.25-30.

[20] Wrolstad, R.E., Durst, R.W., Giusti, M.M. and Rodriguez-Saona, L.E., 2002. Analysis of anthocyanins in nutraceuticals.

[21] Nsimba, R.Y., Kikuzaki, H. and Konishi, Y., 2008. Antioxidant activity of various extracts and fractions of Chenopodium quinoa and Amaranthus spp. seeds. Food chemistry, 106(2), pp.760-766.

[22] Bouayed, J., Hoffmann, L. and Bohn, T., 2011. Total phenolics, flavonoids, anthocyanins and antioxidant activity following simulated gastro-intestinal digestion and dialysis of apple varieties: Bioaccessibility and potential uptake. Food chemistry, 128(1), pp.14-21.

[23] Ang-Lee, M.K., Moss, J. and Yuan, C.S., 2001. Herbal medicines and perioperative care. Jama, 286(2), pp.208-216.

[24] Agume, A.S.N., Njintang, N.Y. and Mbofung, C.M.F., 2017. Effect of soaking and roasting on the physicochemical and pasting properties of soybean flour. Foods, 6(2), p.12. 